ZOOLOGIA 30 (5): 491-498, October, 2013

http://dx.doi.org/10.1590/S1984-46702013000500004

\title{
Vertical structure of an assemblage of bats (Mammalia: Chiroptera) in a fragment of Atlantic Forest in Southern Brazil
}

\author{
Fernando Carvalho',4, Marta E. Fabián² \& João O. Menegheti ${ }^{3}$
}

\author{
1 Programa de Pós-Graduação em Zoologia, Departamento de Zoologia, Universidade Federal do Paraná. Caixa Postal \\ 19020, 81531-980 Curitiba, PR, Brazil. \\ 2 Departamento de Zoologia, Instituto de Biociências, Universidade Federal do Rio Grande do Sul. Avenida Bento Gonçalves \\ 9500, prédio 43435, 91501-970 Porto Alegre, RS, Brazil. \\ ${ }^{3}$ Especialista associado Sul América Programa de Wetlands International. \\ ${ }^{4}$ Corresponding author. E-mail: fernando_bats@yahoo.com.br
}

\begin{abstract}
Few studies have focused the vertical structure of bat assemblages, and how it influences community composition. The goal of this study was to analyze the vertical structure of an assemblage of bats in a forest fragment in southern Brazil. Bats were sampled using mist-nets placed at three heights (understory, below-canopy, and canopy). Forest strata were compared with respect to their species richness and diversity. The latter was estimated using the Shannon-Wiener index $\left(\mathrm{H}^{\prime}\right)$, and the statistical significance of differences among strata was assessed using t tests. We used an index of Constancy $(C)$ to determine the frequency of a given species in each vegetation stratum, such that a species was considered as "frequent" ( $C \geqslant 50)$, "less frequent" $(25 \leqslant C<50)$ and "occasional" $(C<25)$. We captured 485 bats belonging to two families and 24 species. In the understory layer, we captured 173 individuals in 13 species, which resulted in a diversity index of $\mathrm{H}^{\prime}=1.981$. In the under-canopy, 153 individuals were caught in 18 species and the resulting diversity index was $\mathrm{H}^{\prime}=2.509$. Finally, in the canopy, 159 bats were caught, in 22 species, with the resulting diversity index of $\mathrm{H}^{\prime}=2.442$. In the understory and in the canopy, only one species - Artibeus lituratus (Olfers, 1818) was classified as "frequent." Four species - A. lituratus, Sturnira lilium (É. Geoffroy, 1810), Anoura geoffroyi Gray, 1838, and Eptesicus diminutus Osgood, 1915 - were classified as "less frequent" in the under-canopy stratum. All other species recorded in each stratum were classified as "occasional." The studied bat assemblage showed vertical stratification, with the higher strata harboring increased diversity. Our study shows how important it is to sample the upper levels of a forest fragment to obtain a more representative understanding of the use of space by a bat assemblage.
\end{abstract}

KEY WORDS. Diversity; Phyllostomidae; richness; stratification; Vespertilionidae.

Chiroptera is the second largest order of mammals (KALKO 1998). In tropical forests, this group accounts for nearly 40 to $50 \%$ of the total mastofauna, thus strongly affecting richness and diversity patterns (Estrada \& Coates-Estrada 2001). Moreover, bats occupy a variety of trophic niches, including frugivore, nectarivore, carnivore, sanguivore, piscivors, and insectivore species (FLEmING et al. 1972). Due to their considerable feeding plasticity, this group interacts with a broad spectrum of organisms (BERNARD \& Fenton 2007), playing a fundamental role in the maintenance of ecological processes (Kalko 1998, Bernard 2001, Falcão et al. 2003).

Because of the great ecological importance of bat assemblages, several studies have been conducted focusing on their structure (Fleming et al. 1972, Aguirre 2002, Esbérard 2003, BerNARD \& FENTON 2007), particularly with the goal of understanding the factors that allow for the coexistence of such a diverse fauna (Heithaus et al. 1975, Reis 1984, Pedro \& Taddei 1997, Ber-
NARD 2001, Lou \& YurRita 2005 Silva et al. 2008). Out of the factors that have been invoked in promoting diversity, vertical stratification in assemblage composition has gained increasing attention (e.g., KaLKo 1998, Bernard 2001).

Vertical stratification of assemblages has been observed in many animal groups, including invertebrates (e.g., Fermon et al. 2005, Gonçalves \& Louzada 2005, Martins \& Souza 2005, Hirst 2007), and vertebrates (e.g., Passamani 2000, Prevedello et al. 2008). Among the latter, bird assemblages offer good examples of vertical stratification, given that they form clusters of species that occur predominantly at the ground level, on the canopy, and at intermediate levels (e.g., Pearson 1971, Donateli et al. 2007).

In the case of bats, studies on vertical stratification also demonstrate the existence of differences in richness and abundance among strata, both for Megachiroptera (FrancIs 1994, Zubaid 1994, Henry et al. 2004, Hodgkison et al. 2004), and in 
Microchiroptera (Bernard 2001, Lim \& Engstrom 2001, Sampaio et al. 2003, Rex et al. 2008, Pereira et al. 2010). These differences allow some species to be classified as canopy, sub-canopy, or understory specialists (Fleming et al. 1972). However, this division does not imply that these species only use a single stratum (Kalko \& Handley 2001), but rather that they show preference for a given one (SAMPAIO et al. 2003).

Even though having a general knowledge of bat community composition and biology is important to understand the factors that regulate communities, comparatively few studies have addressed the vertical structure of tropical bat assemblages (e.g., Almansa et al. 1982, Francis 1994, Zubaid 1994, Kalko \& Handley 2001, Lim \& Engstrom 2001, Henry et al. 2004, Hodgkison et al. 2004, Rex et al. 2008). In part, this limitation is due to the logistic difficulties associated with sampling canopies (Lim \& ENGSTROM 2001).

Likewise, there are few studies in Brazil that focus on the vertical stratification of bat assemblages (e.g., BERNARD 2001, Kalko \& Handley 2001, Sampaio et al. 2003, Pereira et al. 2010), and the available studies are restricted to the Amazon region. Studies sampling the upper strata of in the Atlantic rainforest, by contrast, have focused only on the compilation of lists of species and their occurrences, with little discussion about the vertical differences in assemblage composition (e.g., EsBÉRARD et al. 2006, Faria 2006, Lourenço et al. 2010). According to LOWMAN \& WiTTMAN (1996), this information gap is of particular concern because making inferences on ecological aspects based on sampling restricted to the understory can result in misleading generalizations and, in many cases, in underestimates of the true diversity and abundance of organisms.

Therefore, the goal of the present study was to analyze the differences in vertical structure of the bat assemblage present in a remnant of Atlantic rainforest in the south of the state of Santa Catarina, southern Brazil.

\section{MATERIAL AND METHODS}

This study was carried out in a fragment of forest located in the municipality of Pedras Grandes $\left(28^{\circ} 29^{\prime} 01^{\prime \prime} \mathrm{S}, 49^{\circ} 15^{\prime \prime} 19^{\prime \prime} \mathrm{W}\right)$, southern state of Santa Catarina (Fig. 1), in a nearly-7-ha area covered mostly by Dense Ombrophilous Forest (Veloso et al. 1992). Floristically, the fragment is composed of areas in early secondary stages of regeneration, in which the canopy may reach 8 to $10 \mathrm{~m}$ in height, and other areas where the vegetation is in a late secondary stage and the canopy reaches from 12 to $20 \mathrm{~m}$. The landscape matrix surrounding the studied fragment is composed of areas used in agriculture, cattle ranching, and native forest fragments. According to the classification of Köeppen, the local climate is $C f a$ (subtropical temperate).

Bat sampling was conducted using mist-nets in three vertical strata of the vegetation: understory GI - set of five mist nets (one of them with dimensions $14 \times 2.5 \mathrm{~m}$, two with $9.0 \times 2.5 \mathrm{~m}$ and two with $7.0 \times 2.5 \mathrm{~m}$ ) placed up to $3 \mathrm{~m}$ above

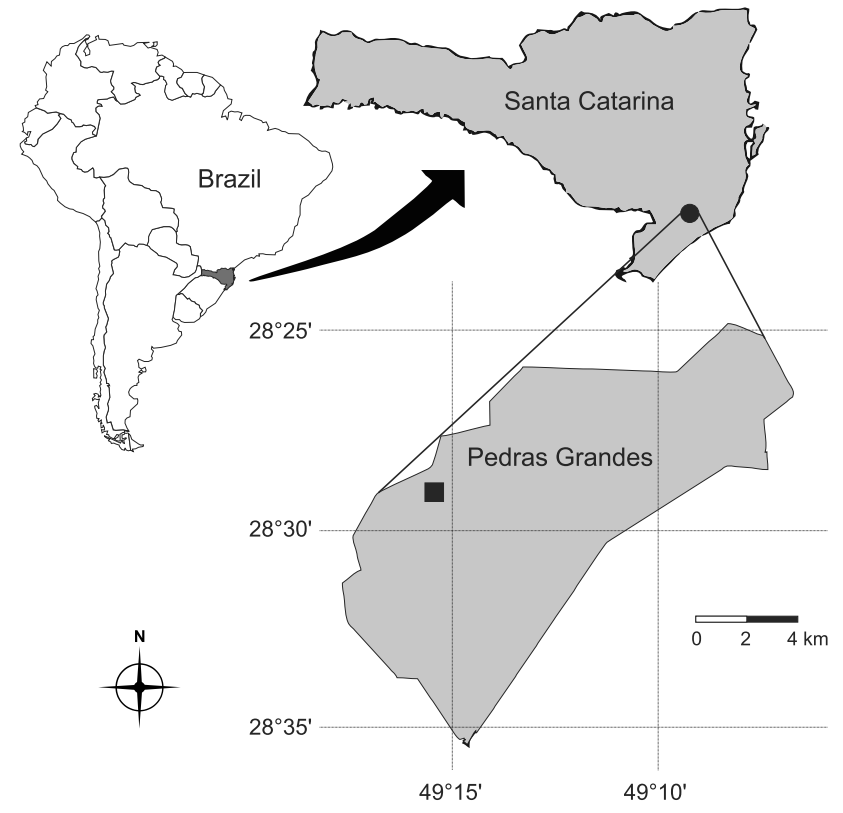

Figure 1. Location map of study area, where: $(\bullet)$ location of the county of Pedras Grandes, southern Santa Catarina state and ( $\square$ ) location of the sampled area.

the ground; below-canopy GII - with five mist nets (one of them with $12 \times 3 \mathrm{~m}$, two with $9 \times 3 \mathrm{~m}$, and two with $6 \times 3 \mathrm{~m}$ ), placed from 4 to $8 \mathrm{~m}$ above the ground; canopy GIII - set of five mist nets (one of them with $12 \times 3 \mathrm{~m}$, two with $9 \times 3 \mathrm{~m}$, and two with $6 \times 3 \mathrm{~m}$ ), placed higher than $9 \mathrm{~m}$ above the ground. We elevated the mist nets using the technique described by CARVALHO \& Fabián (2011a).

We sampled the GI from July 2005 to July 2007, one to two nights per month, for a total of 39 nights. In the case of GII and GIII, sampling took place between October 2009 and September 2010, two to three nights per month, and a total of 35 nights. In GI, GII, and GIII, the corresponding mist-nets remained open for six hours starting at sunset, and being examined every 20 to 40 minutes. Despite the small difference in the number of nights sampled and the size of the mist-nets, the total sampling effort was similar in each stratum, resulting in $26,910 \mathrm{~m}^{2}$.h in the GI and $26,460 \mathrm{~m}^{2}$.h in GII and GIII. Sampling effort was calculated based on the prepositions of STRAUBE $\&$ BIANCONI (2002).

Rainfall and temperature have been documented as important factors in shaping the composition of bat assemblages, affecting mainly the availability of food resources and consequently the abundance of species (e.g., Heithaus et al. 1975, FAlCão et al. 2003, Mello et al. 2008). According to a Student's $\mathrm{t}$ test for paired samples $(\mathrm{a}=0.05)$, using the software PAST (HAMmer et al. 2001), the differences between the monthly averages of these variables for the two sampling periods were not 
significant (Table I). Therefore, we concluded that rainfall and temperature averages were similar between sampling periods, thus justifying pooling both years into the same analysis. Climatic data were obtained from the Company for Agricultural Research and Rural Extension of Santa Catarina (EPAGRI).

Table I. Comparison of average monthly temperature and rainfall during the present study using Student's t test for paired samples.

\begin{tabular}{ccccccc}
\hline \multicolumn{3}{c}{ Rainfall } & & & \multicolumn{3}{c}{ Temperature } \\
\cline { 1 - 2 } \cline { 6 - 7 } Years & $\mathrm{t}$ & $\mathrm{p}$ & & Years & $\mathrm{t}$ & $\mathrm{p}$ \\
\hline $2005 / 2006$ & 0.5258 & 0.6095 & & $2005 / 2006$ & -0.3046 & 0.7663 \\
$2005 / 2007$ & 0.1069 & 0.9168 & & $2005 / 2007$ & 0.0745 & 0.9419 \\
$2005 / 2009$ & -0.8344 & 0.4218 & & $2005 / 2009$ & 0.3519 & 0.7316 \\
$2005 / 2010$ & -0.8456 & 0.4158 & & $2005 / 2010$ & 0.6207 & 0.5474 \\
$2006 / 2007$ & -0.5485 & 0.5943 & & $2006 / 2007$ & 0.3463 & 0.7356 \\
$2006 / 2009$ & -1.4440 & 0.1765 & & $2006 / 2009$ & 0.5341 & 0.6039 \\
$2006 / 2010$ & -1.6440 & 0.1284 & & $2006 / 2010$ & 0.7550 & 0.4661 \\
$2007 / 2009$ & -1.1280 & 0.2835 & & $2007 / 2009$ & 0.2517 & 0.8059 \\
$2007 / 2010$ & -1.3160 & 0.2149 & & $2007 / 2010$ & 0.5316 & 0.6056 \\
$2009 / 2010$ & -0.1870 & 0.8550 & & $2009 / 2010$ & 0.2431 & 0.8124 \\
\hline
\end{tabular}

The bats captured were placed in individual cotton bags, labeled with their collecting data (time and vertical stratum of vegetation) and taken to the field laboratory. After that, we released every individual in the same place where it had been captured. Taxonomic identification was based on TADDEI et al. (1998), Barquez et al. (1999), Velazco (2005), Gardner (2007), and BARQuez \& Díaz (2009). The specimens collected, including those unidentified, were deposited in the collection of mammals from the Department of Zoology, Universidade Federal do Rio Grande do Sul (UFRGS, Appendix 1). The permit to sample bats was provided by the Chico Mendes Institute for Conservation of Biodiversity, number 11528-1 SISBIO (sampling up to 2007) and number 22648-1 SISBIO (sampling up to 2010).

We compared the three strata with respect to richness and diversity of bat assemblages. Species diversity in each stratum was estimated using the Shannon-Wiener index $\left(\mathrm{H}^{\prime}\right)$. A Student's test $(\mathrm{a}=0.05)$ was used to test for differences in $\mathrm{H}^{\prime}$ among strata. Species accumulation curves were constructed for each stratum based on the rarefaction method. For both calculations we used the software PAST (Hammer et al. 2001).

We determined the frequency of species in each stratum using the index of Constancy (C) proposed by SiLVEIRA-Neto et al. (1976), which takes into consideration the number of nights that the taxa were recorded in relation to the total number of samples. Based on the interval of variation of this Index, species were classified as "frequent" $(C \geqslant 50)$, "less frequent" $(25$ $\leqslant \mathrm{C}<50)$, and "occasional" $(\mathrm{C}<25)$.

\section{RESULTS}

We captured a total of 485 bats over the course of 74 nights (total sampling effort of $79,830 \mathrm{~m}^{2} . \mathrm{h}$ ), resulting in a capture success of 0.0060 captures $/ \mathrm{m}^{2}$.h. We identified two families, 15 genera and 24 species (Table II).

Table II. Distribution of bat captures among the three vegetation strata sampled in a forest fragment in southern Brazil. (GI) Understory, (GII) below-canopy, (GIII) canopy, (N) total number of captures.

\begin{tabular}{|c|c|c|c|c|}
\hline \multirow[t]{2}{*}{ Taxa } & \multicolumn{3}{|c|}{ Sampled strata } & \multirow[t]{2}{*}{$\mathrm{N}$} \\
\hline & $\mathrm{Gl}$ & GIl & GIII & \\
\hline \multicolumn{5}{|l|}{ Phyllostomidae } \\
\hline \multicolumn{5}{|l|}{ Carolliinae } \\
\hline Carollia perspicillata (Linnaeus, 1758) & 29 & 8 & 1 & 38 \\
\hline \multicolumn{5}{|l|}{ Desmodontinae } \\
\hline Desmodus rotundus (É. Geoffroy, 1810) & 6 & 3 & 2 & 11 \\
\hline Diphylla ecaudata Spix, 1823 & - & - & 1 & 1 \\
\hline \multicolumn{5}{|l|}{ Glossophaginae } \\
\hline Anoura caudifer (É. Geoffroy, 1818) & 10 & 6 & 5 & 21 \\
\hline Anoura geoffroyi Gray, 1838 & 6 & 20 & 16 & 42 \\
\hline Glossophaga soricina (Pallas, 1766) & - & - & 2 & 2 \\
\hline \multicolumn{5}{|l|}{ Phyllostominae } \\
\hline Chrotopterus auritus (Peters, 1856) & - & 1 & - & 1 \\
\hline Mimon bennettii (Gray, 1838) & 6 & 1 & 1 & 8 \\
\hline \multicolumn{5}{|l|}{ Stenodermatinae } \\
\hline Artibeus fimbriatus Gray, 1838 & 2 & 14 & 18 & 34 \\
\hline Artibeus lituratus (Olfers, 1818) & 68 & 27 & 37 & 132 \\
\hline Artibeus obscurus (Schinz, 1821) & 5 & 7 & 10 & 22 \\
\hline Platyrrhinus recifinus (Thomas, 1901) & - & - & 1 & 1 \\
\hline Pygoderma bilabiatum (Wagner, 1843) & 0 & 6 & 5 & 11 \\
\hline Sturnira lilium (É. Geoffroy, 1810) & 18 & 23 & 29 & 70 \\
\hline Sturnira tildae de la Torre, 1959 & - & 1 & - & 1 \\
\hline Vampyressa pusilla (Wagner, 1843) & - & - & 1 & 1 \\
\hline \multicolumn{5}{|l|}{ Vespertilionidae } \\
\hline \multicolumn{5}{|l|}{ Myotinae } \\
\hline Myotis dinellii Thomas, 1902 & - & - & 1 & 1 \\
\hline Myotis nigricans (Schinz, 1821) & 11 & 2 & 3 & 16 \\
\hline Myotis riparius Handley, 1960 & 1 & 7 & 4 & 12 \\
\hline Myotis ruber (É. Geoffroy, 1806) & 9 & 7 & 6 & 22 \\
\hline \multicolumn{5}{|l|}{ Vespertilioninae } \\
\hline Eptesicus brasiliensis (Desmarest, 1819) & - & 1 & 1 & 2 \\
\hline Eptesicus diminutus Osgood, 1915 & 2 & 13 & 10 & 25 \\
\hline Eptesicus furinalis (d'Orbigny, 1847) & - & 6 & 4 & 10 \\
\hline Lasiurus blossevillii (Lesson, 1826) & - & - & 1 & 1 \\
\hline Number of captures & 173 & 153 & 159 & 485 \\
\hline Richness & 13 & 18 & 22 & 24 \\
\hline
\end{tabular}

ZOOLOGIA 30 (5): 491-498, October, 2013 
In the understory, we captured 173 bats $(35.67 \%$ of all samples) in 13 species. None was found exclusively in this stratum and its diversity index was $\mathrm{H}^{\prime}=1.981$. In the below-canopy, we captured 153 bats ( $31.55 \%$ of all samples) in 18 species. The diversity index was $\mathrm{H}^{\prime}=2.509$. Chrotopterus auritus (W. Peters, 1856) and Sturnira tildae de la Torre, 1959 were only captured in this stratum, although only one individual of each species was captured. In the canopy, we captured 159 bats $(32.78 \%$ of all samples) of 22 species. The diversity index was $\mathrm{H}^{\prime}=2.442$. Diphylla ecaudata Spix, 1823, Platyrrhinus recifinus (O. Thomas, 1901), Vampyressa pusilla (J.A. Wagner, 1843), Glossophaga soricina (Pallas, 1766), Myotis dinellii Thomas, 1902 and Lasiurus blossevillii (Lesson, 1826) were only captured in the canopy. However, with the exception of $G$. soricina, all remaining species were represented by a single individual.

The understory had significantly lower diversity than the below-canopy $(\mathrm{t}=-5.007, \mathrm{p}<0.0001)$ and the canopy $(\mathrm{t}=3.7799$, $p=0.0001)$, whereas no significant differences were detected between below-canopy and the canopy $(t=0.7508, p=0.45337)$.

The differences observed in terms of richness and diversity among the strata are also reflected in richness estimates. The understory accumulation curve showed a strong tendency to an asymptote. This pattern was different from that observed for the other strata, in which accumulation curves showed no tendency to asymptotic behavior (Fig. 2).

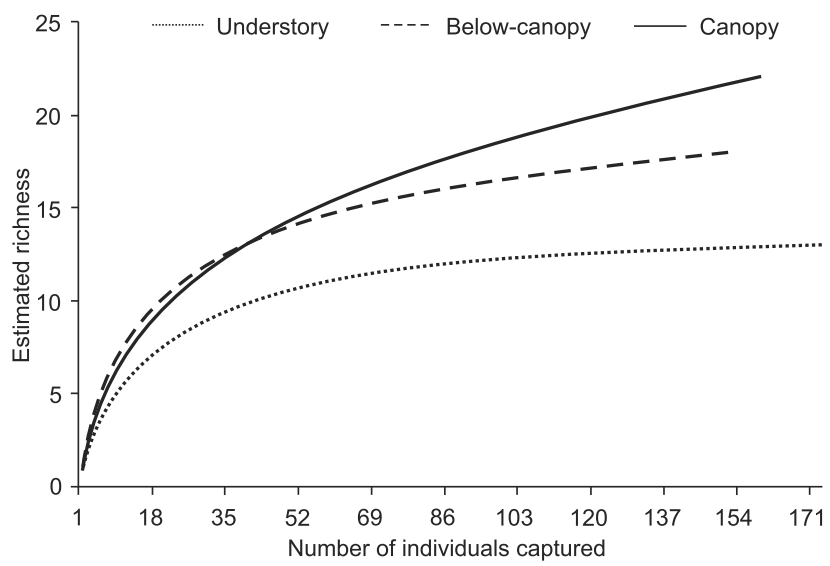

Figure 2. Accumulative curves of species based on the rarefaction method for sampling performed at the level of the understory, below-canopy and canopy remnant of Atlantic Forest in southern Brazil.

Based on the index of Constancy (C), we identified one species classified as "frequent" (Artibeus lituratus (Olfers, 1818)) in the understory, and two other species were considered as "less frequent" (Sturnira lilium (É. Geoffroy, 1810) and Carollia perspicillata (Linnaeus, 1758)). We only categorized three species as "less frequent" in the below-canopy (A. lituratus, S. lilium and Anoura geoffroyi Gray, 1838). Finally, only one species was categorized as "frequent" in the canopy (A. lituratus), whereas four species were classified as "less frequent" (Artibeus fimbriatus Gray 1838, S. lilium, A. geoffroyi, and Eptesicus diminutus Osgood, 1915). The occurrence of other species in each stratum was classified as "occasional" (Table III).

Table III. Index of Constancy (C) proposed by SiLveIRA-Neto et al. (1976) of taxa sampled in each vegetation strata of a forest fragment in southern Brazil. (GI) Understory, (GII) below-canopy, (GIII) canopy.

\begin{tabular}{|c|c|c|c|}
\hline \multirow{2}{*}{ Taxa } & \multicolumn{3}{|c|}{ Index $-\mathrm{C}$ values } \\
\hline & $\mathrm{GI}$ & GII & GIII \\
\hline Anoura caudifer & 15.38 & 17.14 & 11.43 \\
\hline Anoura geoffroyi & 12.82 & $25.71^{\text {** }}$ & $25.71^{* *}$ \\
\hline Artibeus fimbriatus & 2.56 & 22.86 & 31.43 \\
\hline Artibeus lituratus & $51.28^{*}$ & $37.14^{* *}$ & $54.29^{*}$ \\
\hline Artibeus obscurus & 7.69 & 8.57 & 20.00 \\
\hline Carollia perspicillata & $38.46^{* *}$ & 20.00 & 2.86 \\
\hline Chrotopterus auritus & - & 2.86 & - \\
\hline Desmodus rotundus & 10.26 & 5.71 & 2.86 \\
\hline Diphylla ecaudata & - & - & 2.86 \\
\hline Glossophaga soricina & - & - & 5.71 \\
\hline Mimon bennettii & 10.26 & 2.86 & 2.86 \\
\hline Platyrrhinus recifinus & - & - & 2.86 \\
\hline Pygoderma bilabiatum & - & 14.29 & 8.57 \\
\hline Sturnira lilium & $30.77^{* *}$ & 37.14 & $48.57^{* *}$ \\
\hline Sturnira tildae & - & 2.86 & - \\
\hline Vampyressa pusilla & - & - & 2.86 \\
\hline Eptesicus brasiliensis & - & 2.86 & 2.86 \\
\hline Eptesicus diminutus & 5.13 & $28.57^{* *}$ & $28.57^{\star *}$ \\
\hline Eptesicus furinalis & - & 11.43 & 8.57 \\
\hline Lasiurus blossevillii & - & - & 2.86 \\
\hline Myotis dinellii & - & - & 2.86 \\
\hline Myotis riparius & 2.56 & 14.29 & 11.43 \\
\hline Myotis nigricans & 20.51 & 5.71 & 8.57 \\
\hline Myotis ruber & 17.95 & 17.14 & 17.14 \\
\hline
\end{tabular}

\section{DISCUSSION}

The results of the present study demonstrate that the sampled assemblage is structured vertically, forming two main groups. The first is composed by the upper strata (canopy and sub-canopy), which was more diverse, and the second by the lower stratum (understory), which was relatively less diverse when compared with the previous group. This pattern was also observed in other studies on the vertical stratification of Neotropical bat assemblages (Hayes \& GRUver 2000, Bernard 2001, Lim \& Engstrom 2001, Kalko \& Handley 2001, Sampaio et al. 2003, 
Henry et al. 2004, Pereira et al. 2010). The maintenance of this pattern in the Atlantic rainforest environment, where the upper strata are so close to the lower ones (ca. 15-20 m) when compared to the Amazon rainforest (ca. 35-40 m), can be interpreted as an indication that it is common among bat assemblages.

The presence of this vertical structure has also a general implication for studies on bad diversity, given that most of them aim to sample the lower strata (Scultori et al. 2008). Specifically for the forest fragment sampled in this study, if only data from the understory was considered, $54.1 \%$ of the total richness of the area would be sampled, thus underestimating local richness in nearly $46 \%$. Bergallo et al. (2003) underscored the need to use different methods to obtain complete inventories of bat faunas. In the specific case of studies using only mist nets, sampling different strata seems to contribute to more complete surveys (Simons \& Voss 1998, SampaIo et al. 2003), thus demonstrating the importance of sampling different strata, as pointed out by Lowman \& WitTMan (1996) and Kalko \& Handley (2001).

Based on the constancy index of Silveira-Neto et al. (1976) (C), it was possible to identify species that are more frequent in specific strata. This suggests a more common use of these environments. In general, the differential use of strata is associated with aspects of the bat's diet, foraging mode, vegetation structure, and shelter usage (BonACCORSO 1979, KALKO \& HANDLEY 2001, Pereira et al. 2010, Jung et al. 2012). At least for species considered as constant and/or accessory, these factors seem to explain the variation observed in the present study.

Artibeus lituratus was classified as a constant and/or accessory species in all three strata, indicating the broad use of space by this species. Artibeus lituratus mostly feeds on fruits that are available in the canopy, particularly Ficus and Cecropia (e.g., Galleti \& Morellato 1994, Passos et al. 2003). Kalko (1998) pointed out that species of Artibeus frequently use lower strata as transit areas between diurnal shelters and feeding sites. As a consequence, the use of upper strata as foraging sites and lower strata as transit areas can explain the data observed in the present study, as well as corroborate the results of Lim \& ENGSTROM (2001), who consider A. lituratus as being a generalist species with respect to stratum use.

Sturnira lilium was classified as less frequent species in all three forest strata, also indicating a broad use of the vertical space. This species feeds preferentially on fruits of shorter trees (e.g., Passos et al. 2003, Mello et al. 2008), which are available particularly in the understory, but it also feeds on fruits available in the upper strata, such as the fruits of the Billbergia, Ficus, and Cecropia (Fabián et al. 2008, Carvalho et al. 2009a). With respect to shelters, $S$. lilium uses preferentially leaves of tall trees (Evelyn \& STILEs 2003), which correspond to the canopy. The preferential consumption of food items from the lower strata and the use of the diurnal shelters available in the upper strata corroborate the hypothesis that this species is a generalist with respect to the use of strata.
Carollia perspicillata was categorized as constant only in the understory, confirming other studies that place this species as a preferential occupant of the lower stratum (e.g., Bonaccorso 1978, Bernard 2001, Kalko \& Handley 2001). Carollia perspicillata and S. lilium also feed preferentially on fruits of shorter trees (e.g., Mello et al. 2004), and prefer shelters located at the lower strata (Heithaus \& Fleming 1978, Cloutier \& THомаs 1992). Thus, the use of both feeding resources and shelters in the lower strata can explain the spatial distribution of this species.

Eptesicus diminutus was categorized as constant in the subcanopy and the canopy, which also indicates that it uses the upper strata more frequently. This finding is consistent with the foraging mode and diet of this species, which is a flying insectivore (BIANConi \& Pedro 2007). Moreover, the fewer capture events of $E$. diminutus at the sub-canopy when compared with the upper strata, as recorded in the present study, is in agreement with data obtained in surveys carried out exclusively at the ground level in other studies (e.g., EsbéraRd 2003, FALCão et al. 2003, CarvalHo et al. 2009b), which report this species as infrequent. Of all species classified in the present study as rare in all three sampled strata, most are restricted to the sub-canopy and canopy, belonging particularly to the subfamily Stenodermatinae. Members of this subfamily preferentially occupy the upper strata (Pereira et al. 2010), being classified as "canopy frugivores" (Fleming et al. 1972, Bonaccorso 1978). According to Dumont (2005), representatives of this group are adapted to consume Ficus spp. fruits, which are present in high abundance in the area of the present study.

In the case of vespertilionid species, the highest richness was observed in the upper strata (canopy and sub-canopy, $\mathrm{N}=$ 8 spp.) when compared to the understory ( $\mathrm{N}=4 \mathrm{spp}$.). A similar pattern was observed by SAMPAIO et al. (2003), who also observed a larger number of insectivore species in the canopy. Species of Vespertilionidae are usually not well sampled in studies with mist nets set up at the ground level in locations throughout Brazil (e.g., Sipinski \& Reis 1995, Bernard \& Fenton 2007, Esbérard 2003, Reis et al. 2003, Bordignon 2006, Dias \& Peracchi 2008), which is commonly explained by the fact that these bats are more likely to detect the nets (PEDRo \& TADDEI 1997). However, the data obtained in the present study demonstrate that, in addition to net detection, the frequent use of the upper strata might also explain the low representation of the family in surveys carried out at the ground level.

Out of the 47 bat species currently recorded in Santa Catarina (Passos et al. 2010, Carvalho \& Fabián 2011b), 24 species $(51.06 \%)$ were recorded in samplings carried out at three strata in the forest fragment investigated in the present study. If one takes into account only the two families that were recorded (Phyllostomidae and Vespertilionidae), the proportion of the bat fauna recorded in the state is even higher (64.86\%). These results demonstrate that, in addition to providing data on the vertical occupation of environments, studies address- 
ing aspects related to the vertical structure of assemblages provide a better understanding of the diversity in a given region, given that they yield more complete surveys.

\section{ACKNOWLEDGMENTS}

We thank CAPES for the Master's scholarship provided to F. Carvalho between 2009-2010, and CNPQ for the doctoral scholarships provided to F. Carvalho. We also thank A. Karolina S. Souza, Poliana B. Peres, Rodrigo Á. Mendonça, Rildo V. Gonçalves and Flávia V. Fonceca for assistance during field work.

\section{LITERATURE CITED}

AguiRRe, L.F. 2002. Structure of a neotropical savanna bat community. Journal of Mammalogy 83 (3): 775-784.

Almansa, J.C.; L.M.A. Martinez \& C.I. Ulargui. 1982. Uso del espacio y movimientos en una comunidad de quiropteros neotropicales. Historia Natural 2 (21): 177-190.

Barquez, R. M. \& M.M. Díaz. 2009. Los murciélagos de Argentina: Clave de Identificación. Tucumán, 1+80p.

Barquez, R.M.; M.A. Mares \& J.K. Braun. 1999. Bats of Argentina. Special Publications Museum of Texas Tech University 42: 1-275.

Bergallo, G.H.; Ce.L. Esbérard; M.A.R. Mello; V. Lins; R. Mangolin; G.S.S. Melo \& M. Baptista. 2003. Bat Species Richness in Atlantic Forest: What Is the Minimum Sampling Effort? Biotropica 35 (2): 278-288.

BERNARD, E. 2001. Vertical stratification of bat communities in primary forests of Central Amazon, Brazil. Journal of Tropical Ecology 17: 115-126.

Bernard, E. \& M.B. Fenton. 2007. Bats in a fragmented landscape: Species composition, diversity and habitat interactions in savannas of Santarém, Central Amazonia, Brazil. Biological Conservation 34: 332-343.

Bianconi, G. \& W.A. Pedro. 2007. Família Vespertilionidae, p. 167-195. In: N.R. Reis; A.L. Peracchi; W.A. Pedro \& I.P. Lima (Eds). Morcegos do Brasil. Londrina, Universidade Estadual de Londrina, 253p.

BonacCoRso, F.J. 1979. Foraging and Reproductive Ecology in a Panamanian Bat Community. Bulletin of the Florida State Museum. Biological Sciences 24 (4): 359-408.

Bordignon, M.O. 2006. Diversidade de morcegos (Mammalia, Chiroptera) do Complexo Aporé-Sucuriú, Mato Grosso do Sul, Brasil. Revista Brasileira de Zoologia 23 (4): 1002-1009.

Carvalho, F. \& M.E. Fabián. 2011a. Método de elevação de redes de neblina em dosséis florestais para amostragem de morcegos (Mammalia; Chiroptera). Chiroptera Neotropical 17 (1): 795-802.

Carvalho, F. \& M.E. Fabián. 2011b. Mammalia, Chiroptera, Phyllostomidae, Platyrrhinus recifinus (O. Thomas, 1901): first record in the state of Santa Catarina, Southern Brazil. Check-List 7 (2): 139-141.
Carvalho, F., M.E. Fabián \& R.A. Mendonça 2009a. Nota sobre o consumo de frutos de Billbergia zebrina (Bromeliaceae) por Sturnira lilium (Chiroptera: Phyllostomidae) no sul do Brasil. Chiroptera Neotropical 15 (2): 482-486.

Carvalho, F.; J.J. Zocche \& R.A. Mendonça. 2009b. Morcegos (Mammalia, Chiroptera) em restinga no município de Jaguaruna, sul de Santa Catarina, Brasil. Revista Biotemas 22 (3): 193-201.

Cloutier, D. \& D.W. Thomas. 1992. Carollia perspicillata. Mammalian Species 417: 1-9.

Dias, D. \& A.L. Peracchi. 2008. Quirópteros da Reserva Biológica do Tinguá, estado do Rio de Janeiro, sudeste do Brasil (Mammalia: Chiroptera). Revista Brasilera de Zoologia 25 (3): 333-369.

Donatelli, R.J.; C.D. Ferreira; A.C. Dalbeto \& S.R. Posso. 2007. Análise comparativa da assembléia de aves em dois remanescentes florestais no interior do Estado de São Paulo, Brasil. Revista Brasileira de Zoologia 24 (2): 362-375.

Dumont, E.R. 2005. Bats and Fruit: na ecomorphological approach, p. 398-429. In: T.H. Kunz \& M.B. Fenton (Eds). Bats Ecology. Chicago, University Press.

EsbéraRd, C.E.L. 2003. Diversidade de morcegos em área de Mata Atlântica regenerada no sudeste do Brasil. Revista Brasileira de Zoociências 5 (2): 189-204.

Esbérard, C.E.L.; T. Jordão-Nogueira; J.L. Luz; G.G.S. Melo; R. Mangolin; N. Jucá; D.S.L. Raíces; M.C. Enrici \& H. Bergallo. 2006. Morcegos da Ilha Grande, Angra dos Reis, RJ, Sudeste do Brasil. Revista Brasileira de Zoociências 8 (2): 147-153.

Estrada, A. \& R. Coates-Estrada. 2001. Bat species richness in live fences and corridors of residual rain forest vegetation at Los Tuxtlas, Mexico. Ecography 24: 94-102.

Evelyn, M.J. \& D.A. Stiles. 2003. Roosting Requirements of Two Frugivorous Bats (Sturnira lilium and Arbiteus intermedius) in Fragmented Neotropical Forest. Biotropica 35 (3): 405-418.

Fabián, M.E., A.M. Rui \& J.L. Waechter. 2008. Plantas utilizadas como alimento por morcegos (Chiroptera, Phyllostomidae), no Brasil, p. 51-70. In: N.R. Reis; A.L. Peracchi \& G.A.S.D. SANTOS (Eds) Ecologia de morcegos. Londrina, Technical Books Editora, 148p.

Falcão, C.F.; F.V. Rebelo \& A.S. Talamoni. 2003. Structure of a bat assemblage (Mammalia, Chiroptera) in Serra do Caraça Reserve, South-East Brazil. Revista Brasileira de Zoologia 20 (2): 347-350.

FARIA, D. 2006. Phyllostomid bats of a fragmented landscape in the north-eastern Atlantic forest, Brazil. Journal of Tropical Ecology 22: 531-542.

Fermon, H.; M. Waltert; R.I. Vane-Wright \& M. Mühlenberg. 2005. Forest use and vertical stratification in fruit-feeding butterflies of Sulawesi, Indonesia: impacts for conservation. Biodiversity and Conservation 14: 333-350.

Fleming, T.H.; E.T. Hooper \& D.E. Wilson. 1972. Three central American bat communities: Structure, reproductive cycles and movement patterns. Ecology 53 (4): 555-569. 
FRANCIS, C.M. 1994. Vertical stratification of fruit bats in lowland rain forests of Malaysia. Journal of Tropical Ecology 10: 523-530.

Galetti, M. \& L.P.C. Morellato. 1994. Diet of the large fruiteating Artibeus lituratus in a forest fragment in Brazil. Mammalia 58 (4): 661-665.

Gardner, A.L. 2007. Mammals of South America. Chicago, University Press, 669p.

GonÇALVES, T.T. \& J.N.C. LouZADA. 2005. Estratificação vertical de coleópteros carpófilos (Insecta: Coleoptera) em fragmentos florestais do sul do Estado de Minas Gerais, Brasil. Ecología Austral 15: 101-110.

Hammer, O., D.A.T. Harper \& P.D. Ryan. 2001. Past: Palaeontological Statistc Software package for education and data analysis. Palaeontologia Electronica 4 (1): 1-9.

HAyes, J.P. \& J.C. Gruver. 2000. Vertical stratification of bat activity in an Old-Growth Forest in Western, Washington. Northwest Science 74 (2): 102-108.

Heithaus, E.R. \& T.H. Fleming. 1978. Foraging Movements of a Frugivorous Bat, Carollia perspicillata (Phyllostomatidae). Ecological Monographs 48 (2): 127-143.

Heithaus, E.R.; T.H. Fleming \& P.A. Opler. 1975. Foraging Patterns and Resource Utilization in Seven Species of Bats in a Seasonal Tropical Forest. Ecology 56 (4): 841-854.

Henry, M.; A. Gautier-Hion \& M. Colyn. 2004. Species composition, abundance and vertical stratification of a bat community (Megachiroptera: Pteropodidae) in a West African rain forest. Journal of Tropical Ecology 20: 21-29.

Hirst, A.J. 2007. Vertical stratification of mobile epiphytal arthropod assemblages between the canopy and understorey of subtidal macroalgae. Marine Biology 150: 427-441.

Hodgkison, R., S.T. Balding, A. Zubaid \& T.H. Kunz. 2004. Habitat structure, wing morphology, and the vertical stratification of Malaysian fruit bats (Megachiroptera: Pteropodidae). Journal of Tropical Ecology 20: 667-673.

Jung, K.; S. Kaiser; S. BöHm; J. Nieschulze \& E.K.V. Kalko. 2012. Moving in three dimensions: effects of structural complexity on occurrence and activity of insectivorous bats in managed forest stands. Journal of Applied Ecology 49: 523-531.

KALKO, E.K.V. 1998. Organisation and diversity of tropical bats communities through space and time. Zoology 111: 281297.

Kalko, E.K.V. \& C.O. Handley. 2001. Neotropical bats in the canopy: diversity, community structure, and implications for conservation. Plant Ecology 153: 319-333.

Lim, B.K. \& M.D. Engstrom. 2001. Bat community structure at Iwokrama Forest, Guyana. Journal of Tropical Ecology 17: 647-665.

Lou, S. \& C.L. YurRita. 2005. Análisis de nicho alimentario en la comunidad de murciélagos frugívoros de Yaxhá, Petén, Guatemala. Acta Zoológica Mexicana 21 (1): 83-94.

Lourenço, E.C.; L.M. Costa \& C.E.L. EsbÉRARD. 2010. Bat diversity of Ilha da Marambaia, Southern Rio de Janeiro State, Brazil
(Chiroptera, Mammalia). Brazilian Journal of Biology 70 (3): 511-519.

Lowman, M.D. \& P.K. WitTman. 1996. Forest canopies: Methods, Hypotheses, and Future Directions. The Annual Review of Ecology, Evolution, and Systematics 27: 55-81.

Martins, C.F. \& A.K.P. SouzA. 2005. Estratificação vertical de abelhas Euglossina (Hymenoptera, Apide) em uma área de Mata Atlântica, Paraíba, Brasil. Revista Brasileira de Zoologia 22 (4): 913-918.

Mello, M.A.R.; G.M. Schittini; P. Selig \& H.G. Bergallo. 2004. A test of the effects of climate and fruiting of Piper species (Piperaceae) on reproductive patterns of the bat Carollia perspicillata (Phyllostomidae). Acta Chiropterologica 6 (2): 309-318.

Mello, M.A.R.; E.K.V. Kalko \& W.R. Silva. 2008. Diet and abundance of the bat Sturnira lilium (Chiroptera) in a brazilian montane Atlantic Forest. Journal of Mammalogy 89 (2): 485-492.

Passamani, M. 2000. Análise da comunidade de marsupiais de Santa Tereza, Espírito Santo. Boletim do Museu de Biologia Mello Leitão 11 (12): 215-228.

Passos, F.C.; W.R. Silva; W.A. Pedro \& R.M. Bonin. 2003. Frugivoria em morcegos (Mammalia, Chiroptera) no Parque Estadual Intervales, sudeste do Brasil. Revista Brasileira de Zoologia 20 (3): 511-517.

Passos, F.C.; J.M.D. Miranda; I.P. Bernardi; N.Y. Kaku-Oliveira \& L.C. Munster. 2010. Morcegos da Região Sul do Brasil: análise comparativa da riqueza de espécies, novos registros e atualizações nomenclaturais (Mammalia, Chiroptera). Iheringia 100 (1): 25-34.

Pearson, D.L. 1971. Vertical stratification of birds in a tropical dry forest. The Condor 73: 46-55.

Pedro, W.A. \& V.A. Tadder. 1997. Taxonomic assemblage of bats from Panga Reserve, southeastern Brazil: abundance patterns and trophic relations in the Phyllostomidae (Chiroptera). Boletin do Museu de Biologia Mello Leitão 6: 3-21.

Pereira, M.J.R.; J.T. Marques \& J.M. Palmeirim. 2010. Vertical stratification of bat assemblages in flooded and unflooded Amazonian forests. Current Zoology 56 (4): 469-478.

Prevedello, J.A.; A.F. Mendonça \& M.V. Vieira. 2008. Uso do espaço por pequenos mamíferos: uma análise dos estudos realizados no Brasil. Oecologia Brasiliensis 12 (4): 610-625.

ReIs, N.R. 1984. Estrutura de comunidade de morcegos na região de Manaus, Amazonas. Revista Brasileira Biologia 44 (3): 247-254.

Reis, N.R.; M.L.S. Barbieri; I.P. Lima \& A.L. Peracchi. 2003. O que é melhor para manter a riqueza de espécies de morcegos (Mammalia; Chiroptera): um fragmento florestal grande ou vários fragmentos de pequeno tamanho? Revista Brasileira de Zoologia 20 (2): 225-230.

ReX, K.; D.H. Kelm; K. Wiesner; T.H. Kunz \& C.C. Voigt. 2008. Species richness and structure of three Neotropical bat assemblages. Biological Journal of the Linnean Society 94: 617-629. 
Sampaio, E.M., E.K.V. Kalko, E. Bernard, B. Rodriguéz-Herrera \& C.O. Handley. 2003. A Biodiversity Assessment of Bats (Chiroptera) in a Tropical Lowland Rainforest of Central Amazonia, Including Methodological and Conservation Considerations. Studies on Neotropical Fauna and Environment 38 (1): 17-31.

Scultori, C.; S. Von Matter \& A.L. Peracchi. 2008. Métodos de amostragem de morcegos em sub-dossel e dossel florestal, com ênfase em redes de neblina, p. 17-32. In: N.R. ReIs; A.L. Peracchi \& G.A.S.D. SANTos (Eds) Ecologia de morcegos. Londrina, Technical Books Editora, 148p.

Silva, A.G.; O.Gaona \& R.A. Medellín. 2008. Diet and trophic structure in a community of fruit-eating bats in lacandon forest, México. Journal of Mammalogy 89 (1): 43-49.

Silveira-Neto, S.O.; D. Nakano \& N.A.V. Nova. 1976. Manual de ecologia dos insetos. Piracicaba, Ceres, 419p.

Simons, N.B. \& R.S. Voss. 1998. The mammals of Paracou, French Guiana: A neotropical lowland rainforest fauna. Part 1: bats. Bulletin American Museum Natural History 237: 1-219.

Sipinski, E.A.B. \& N.R. Reis. 1995. Dados ecológicos dos quirópteros da Reserva Volta Velha, Itapoá, Santa Catarina, Brasil. Revista Brasileira Zoologia 12 (3): 519-528.

Straube, F.C. \& G.V. Bianconi. 2002. Sobre a grandeza e a unidade utilizada para estimar esforço de captura com utilização de redes-de-neblina. Chiroptera Neotropical 8 (1-2): 150153.

Taddei, V.A.; C.A. Nobile \& E. Morielle-Versute. 1998. Distribuição geográfica e análise morfométrica comparativa em Artibeus obscurus (Schinz, 1821) e A. fimbriatus Gray 1838 (Mammalia: Chiroptera: Phyllostomidae). Ensaios e Ciência 2 (2): 71-127.

Velazco, P.M. 2005. Morphological Phylogeny of the Bat Genus Platyrrhinus Saussure, 1860 (Chiroptera: Phyllostomidae) with the Description of Four New Species. Fieldiana 105: 1-54.

Veloso, H.P.; L.C. Oliveira-Filho A.; M.S.F. Vaz; M.P.M. Lima; R. Marquete \& J.E.M. Brazao. 1992. Manual técnico da vegetação brasileira. Rio de Janeiro, Fundação Instituto Brasileiro de Geografia e Estatística, 92p.

ZubaID, A. 1994. Vertical stratification of pteropodid bats in a Malaysian lowland rainforest. Mammalia 58: 309-311.

Appendix I. List of specimens, collected in remnant of Atlantic Forest in southern Brazil, and respective deposit number in the Collection of Mammals from the Department of Zoology, Universidade Federal do Rio Grande do Sul (UFRGS)

Anoura caudifer: 1059; Anoura geoffroyi: 1072, 1167; Artibeus fimbriatus: 1163, 1046, 1161, 1141, 1142, 1145, 1146, 1147, 1151, 1154, 1156, 1158, 1219, 1220, 1222, 1225, 1301; Artibeus lituratus: 1035, 1037, 1143, 1144, 1148, 1150, 1153, 1155, 1157, 1159, 1160, 1162,1218, 1221, 1300; Artibeus obscurus: 1030, 1047, 1149, 1223, 1224; Carollia perspicillata: 1057, 1298; Chrotopterus auritus: 1298; Diphylla ecaudata: 1165; Eptesicus brasiliensis: 1185, 1171; Eptesicus diminutus: 1092, 1120, 1182, 1204, 1232; Eptesicus furinalis: 1170, 1174, 1175, 1178, 1205, 1207; Glossophaga soricina: 1169; Lasiurus blossevillii: 1188; Mimon bennettii: 1056; Myotis dinellii: 1196; Myotis nigricans: 1105,1121, 1122, 1123,1124, 1125, 1127, 1128, 1177, 1195, 1231, 1234; Myotis riparius: 1115, 1173, 1179, 1180, 1190, 1192, 1198, 1233, 1238, 1239; Myotis ruber: 1111, 1172, 1181, 1186, 1189; Platyrrhinus recifinus: 1230; Pygoderma bilabiatum: 1164; Sturnira lilium: 1055, 1166; Sturnira tildae: 1296, 1297; Vampyressa pusilla: 1168.

Submitted: 07.X.2012; Accepted: 13.III.2013.

Editorial responsibility: Fernando de C. Passos

ZOOLOGIA 30 (5): 491-498, October, 2013 